\title{
UJI AKTIVITAS ANTIOKSIDAN EKSTRAK BAWANG PUTIH (Allium sativum)
}

\author{
Djuned Prasonto ${ }^{\star}$ Eriska Riyanti**, Meirina Gartika**
}

\begin{tabular}{c}
\hline Keywords: \\
Antioxidant, DPPH \\
(1,1-difenil-2- \\
pikrilhidrazil), Garlic \\
(Allium sativum)
\end{tabular}

Background: Organosulfur compound, allicin and phenolic are the main compound in garlic responsible for antioxidant activity. Correlation between free radicals and some dental diseases, such as free radicals and Reactive Oxygen Species (ROS) responsible for periodontal inflammation, caries, lesions and oral cancers. The research objective is to get scientific data about the antioxidant activity from garlic extract (Allium sativum).

Method: The research was conducted using three different varieties of garlic: local garlic varieties Ciwidey, single local garlic's clove, and import garlic which is found at the market in Bandung. Garlic extract is made by maceration using ethanol 96\% and antioxidant activity test using DPPH method (1,1-diphenyl-2picrylhydrazyl). Statistical analysis using One Way ANOVA followed by post hoc analysis

Result: three varieties of garlic have a strong antioxidant activity. Value of IC50 $=13.61 \mathrm{mg} / \mathrm{ml}$ for local garlic varieties Ciwidey, IC50 = $10.61 \mathrm{mg} / \mathrm{ml}$ for single local garlic's clove and IC50 = $11.32 \mathrm{mg} / \mathrm{ml}$ for imports garlic.

Conclusion: Three varieties of garlic have different antioxidant strength and the best antioxidant strength is single local garlic's clove.

\section{PENDAHULUAN}

Kandungan senyawa fenolik seperti flavonoid, turunan coumarin dan lainnya yang terkandung di dalam bahan tanaman tertentu diketahui dapat menangkal stres oksidatif di tubuh manusia dengan cara membantu mempertahankan keseimbangan antara oksidan dan antioksidan. Stres oksidatif adalah suatu keadaan ketika kandungan oksidan dan radikal bebas di dalam tubuh lebih banyak dibandingkan antioksidan. ${ }^{1}$

Radikal bebas sering dikaitkan dengan berbagai peristiwa patologis seperti peradangan, penuaan, dan penyebab kanker. Radikal bebas (free radical) adalah atom atau molekul yang mempunyai elektron tidak berpasangan, terbentuk sebagai hasil antara (intermediet) dalam suatu reaksi organik melalui proses homolisis dari ikatan kovalen. Reaktivitas senyawa radikal bebas akan secepat mungkin menyerang komponen seluler yang berada disekelilingnya seperti senyawa lipid, lipoprotein, protein, karbohidrat, RNA, maupun DNA. Akibat reaktivitas radikal bebas akan menimbulkan terjadinya kerusakan struktur maupun fungsi sel. ${ }^{2}$

Penggunaan antioksidan sintetik seperti butylated hydroxytoluen (BHT), butylated hydroxyanisole (BHA), dan tertbutylhydroxy quinone (TBHQ) telah dibatasi pada produkproduk makanan karena dianggap memiliki efek karsinogenik. Hal ini yang mendorong berbagai penelitian untuk menemukan sumber antioksidan baru yang berasal dari alam yang diharapkan dapat mengganti antioksidan sintetik. $^{2}$

Berbagai jenis tumbuhan yang menjadi

* Staf pengajar Prodi Kedokteran Gigi Universitas Yarsi, ** Staf pengajar Fakultas Kedokteran Gigi Universitas Padjadjaran

Korespondensi: djunedprasonto@gmail.com 
sumber potensial sebagai bahan terapeutik adalah bawang putih (Allium sativum). Telah banyak diteliti khasiat bawang putih (Allium sativum) sebagai bahan terapeutik mulai dari sebagai antibakteri, antivirus, anti jamur, anti thrombotik, antibiotik, antikanker, antioksidan, immunomodulator, antiinflamasi, dan efek hipoglikemik. ${ }^{3,4}$

Organosulfur dan senyawa fenolik sebagai antioksidan yang terdapat dalam kandungan bawang putih memegang peranan sangat penting untuk mencegah kerusakan sel dan organ dari proses oksidasi. ${ }^{5,6}$ Senyawa fenolik dari bawang putih memiliki kelompok berjumlah satu atau lebih yaitu sebagai donor proton hidrogen dan menetralisir radikal bebas. Antioksidan melindungi tubuh dari radikal bebas dan efek Reactive Oxygen Species (ROS). Reactive Oxygen Species (ROS) seperti anion superoksida (O2), hidroksil $(-\mathrm{OH})$, peroksil (ROO-), radikal alkoksil (RO-), dan hidrogen peroksida (H2O2) inilah yang akan

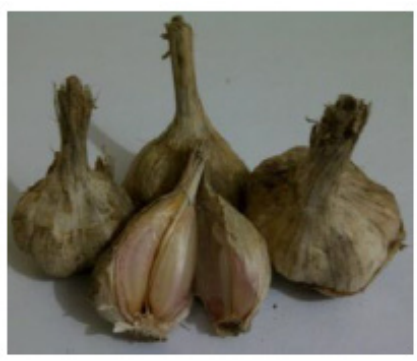

Gambar 1. Bawang putih lokal varietas Ciwidey menyerang protein, lipid dan atau membuat kerusakan DNA sehingga menyebabkan penyakit. $^{5}$

Terdapat hubungan antara radikal bebas dan beberapa penyakit di bidang kedokteran gigi, diantaranya yaitu Reactive Oxygen Species (ROS) bertanggungjawab pada peradangan periodontal, terjadinya karies, lesi dan kanker mulut. ${ }^{7}$ Antioksidan sangat berperan untuk mencegah dan mengobati penyakit tersebut. ${ }^{7,8,9,10}$

Terdapat beberapa jenis varietas bawang putih dan penelitian ini menggunakan sampel tiga jenis varietas yang sering dijumpai di pasaran Kota Bandung. Varietas bawang putih yang digunakan adalah bawang putih lokal varietas Ciwidey, bawang putih lokal siung tunggal, dan bawang putih impor.

Penelitian ini menggunakan proses pembuatan ekstrak bawang putih secara maserasi dengan pelarut etanol. Pemilihan etanol sebagai pelarut karena kemampuan

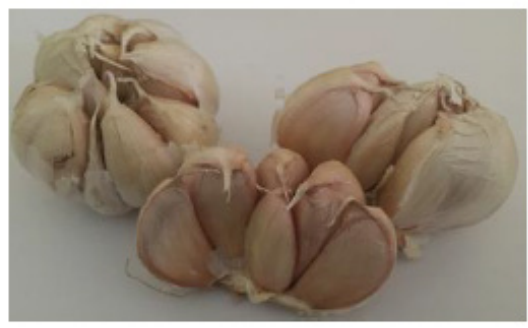

Gambar 2. Bawang putih impor

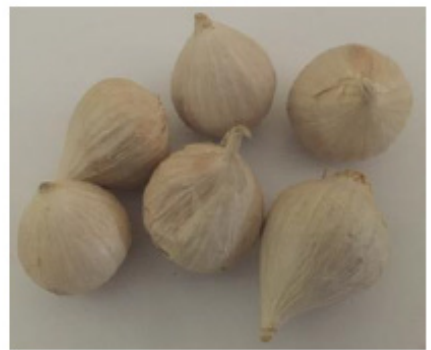

Gambar 3. Bawang putih lokal siung tunggal 
etanol yang lebih baik dalam menarik bahan aktif di dalam ekstrak dibandingkan dengan pelarut lainnya, mudah dan relatif murah. Pada dasarnya proses pembuatan ekstrak dapat digunakan berbagai macam pelarut selain etanol diantaranya yaitu air destilasi, petroleum ether, etil asetat, heksan, kloroform dan metanol. ${ }^{11-15}$

Penelitian terhadap ekstrak bawang putih dengan pelarut etanol sebagai bahan penghambat proses karies pernah dilakukan sebelumnya. ${ }^{16}$ Namun penelitian mengenai uji aktivitas antioksidan pada bawang putih belum pernah dilakukan oleh karena itu maka penulis tertarik untuk meneliti tentang uji aktivitas antioksidan pada ekstrak bawang putih (Allium sativum).

\section{METODE PENELITIAN}

Metode untuk menentukan aktivitas antioksidan pada penelitian ini menggunakan metode uji aktivitas antioksidan DPPH (1,1-difenil-2- $\quad$ pikrilhidrazil). ${ }^{17,18,19} \quad$ DPPH merupakan radikal bebas yang stabil pada suhu kamar dan sering digunakan untuk menilai aktivitas antioksidan beberapa senyawa atau ekstrak bahan alam. 17,18 Interaksi antioksidan dengan DPPH baik secara transfer elektron atau radikal hidrogen pada DPPH akan menetralkan karakter radikal bebas dari DPPH. $17,18,19$

Beberapa keuntungan dengan menggunakan metode ini yaitu pengerjaannya cepat, sederhana dan membutuhkan peralatan yang cukup sederhana. Semakin rendah nilai $I C_{50}$ dari uji aktivitas antioksidan metode DPPH maka zat/bahan tersebut akan semakin mempunyai sifat antioksidan yang tinggi. 17-22

Jenis penelitian adalah penelitian eksperimental laboratorik dengan rancangan penelitian kuantitatif eksperimental. Bahan/ Subjek/Objek Penelitian Bawang putih lokal varietas Ciwidey, bawang putih lokal siung tunggal, dan bawang putih impor yang dibeli di pasar Kota Bandung. Kriteria inklusi dari penelitian ini adalah: 1) Bawang putih lokal varietas Ciwidey, bawang putih lokal siung tunggal dan bawang putih impor. 2) Bagian bawang putih yang digunakan yaitu umbi bawang putih/siung. 3) Bawang putih segar. Sedangkan kriteria eksklusinya adalah: 1) Bawang putih busuk dan layu.

\section{HASIL PENELITIAN}

Penelitian ini menggunakan sampel bawang putih dari tiga varietas yaitu bawang putih lokal varietas Ciwidey, bawang putih lokal siung tunggal, dan bawang putih impor. Bawang putih diekstraksi dengan metode maserasi menggunakan pelarut etanol $96 \%$.

Setelah dilakukan ekstrak pada masingmasing sampel kemudian dilakukan pengujian aktivitas antioksidan dengan menggunakan metode DPPH (1,1-difenil-2-pikrilhidrazil). Parameter ukuran yang dipakai untuk menunjukkan aktivitas antioksidan adalah nilai konsentrasi inhibisi atau biasa disebut Inhibition Concentration $\left(\mathrm{IC}_{50}\right)$ yaitu konsentrasi suatu zat antioksidan yang dapat menyebabkan $50 \%$ DPPH (1,1-difenil-2-pikrilhidrazil) kehilangan karakter radikal atau konsentrasi suatu zat antioksidan yang memberikan persentase (\%) penghambatan $50 \%$. Zat yang mempunyai aktivitas antioksidan tinggi, akan mempunyai nilai $\mathrm{IC}_{50}$ yang rendah. Nilai $\mathrm{IC}_{50}$ dari ketiga varietas bawang putih seperti pada Tabel 1 .

Tabel 1 memperlihatkan bahwa bawang putih lokal siung tunggal mempunyai nilai $\mathrm{IC}_{50}$ yang lebih kecil dibandingkan dengan varietas bawang putih lainnya, artinya bahwa 
Tabel 1 Nilai IC ${ }_{50}$ Ketiga Varietas Bawang Putih (Allium sativum)

\begin{tabular}{cc}
\hline Varietas Bawang Putih (Allium sativum) & $\mathrm{IC}_{50}(\mathrm{mg} / \mathrm{ml})$ \\
\hline $\begin{array}{l}\text { 1. Bawang putih lokal varietas } \\
\text { Ciwidey }\end{array}$ & 13,61 \\
2. Bawang putih lokal siung tunggal & 10,61 \\
3. Bawang putih impor & 11,32 \\
\hline
\end{tabular}

Tabel 2 Uji Statistik One Way ANOVA Ketiga Varietas Bawang Putih

\begin{tabular}{cccccc}
\hline Source & $S S$ & Df & MS & $F$ & $p$-value \\
\hline Treatment & 14,7482 & 2 & 7,37410 & 39,08 & $0,0004^{*}$ \\
Error & 1,1322 & 6 & 0,18870 & & \\
\hline Total & 15,8804 & 8 & & & \\
\hline
\end{tabular}

Tabel 3 Uji Statistik Post Hoc Ketiga Varietas Bawang Putih

\begin{tabular}{lcccc}
\hline $\begin{array}{c}\text { Varietas Bawang } \\
\text { Putih (Allium } \\
\text { sativum) }\end{array}$ & \multicolumn{1}{c}{$\begin{array}{c}\text { Bawang } \\
\text { putih lokal } \\
\text { siung tunggal }\end{array}$} & $\begin{array}{c}\text { Bawang } \\
\text { putih impor }\end{array}$ & $\begin{array}{c}\text { Bawang } \\
\text { putih lokal } \\
\text { varietas } \\
\text { Ciwidey }\end{array}$ \\
\cline { 2 - 5 } & $\mathrm{IC}_{50}$ & 10,61 & 11,32 & 13,61 \\
\hline $\begin{array}{l}\text { Bawang putih lokal } \\
\text { siung tunggal }\end{array}$ & 10,61 & & & \\
\hline Bawang putih impor & 11,32 & 0,0693 & & \\
\hline $\begin{array}{l}\text { Bawang putih lokal } \\
\text { varietas Ciwidey }\end{array}$ & 13,61 & $0,0021^{*}$ & $0,0025^{*}$ & \\
\hline
\end{tabular}

bawang putih lokal siung tunggal memiliki baik dibandingkan keduanya.

daya antioksidan yang lebih baik dibandingkan dengan varietas bawang putih yang lainnya.

\section{DISKUSI}

Berdasarkan Tabel 2 menunjukkan bahwa diantara masing-masing ketiga varietas bawang putih mempunyai perbedaan $\mathrm{IC}_{50}$ yang signifikan pada uji statistik One Way ANOVA dengan Pvalue <0,05.

Penelitian ini bertujuan untuk uji aktivitas antioksidan bawang putih dengan terlebih dahulu melakukan ekstrak bawang putih menggunakan metode maserasi dan pelarut

Tabel 3 memperlihatkan bahwa ketiga bawang putih tersebut memiliki daya antioksidan namun bawang putih lokal siung tunggal memiliki daya antioksidan yang lebih yang digunakan yaitu etanol. Pembuatan ekstrak dengan metode maserasi dipilih karena metode ini sederhana, banyak digunakan dalam penelitian untuk melakukan ekstrak 
tanaman herbal, dan metode ini digunakan pada senyawa yang tidak tahan panas (termolabil) seperti bawang putih. Pelarut etanol dipilih karena mempunyai polaritas yang tinggi sehingga dapat mengekstrak bahan lebih banyak dibandingkan jenis pelarut organik yang lain dan mempunyai titik didih yang rendah. ${ }^{13}$

Penelitian terdahulu membandingkan antara ekstraksi menggunakan metode maserasi dengan pelarut etanol dan pelarut air pada umbi bawang dayak (Eleutherine palmifolia), hasil analisis fitokimia dari ekstraksi dengan pelarut etanol didapatkan kandungan senyawa kimia alkaloid, tanin, fenolik, flavonoid dan triterpenoid dibandingkan ekstraksi dengan pelarut air hanya didapatkan kandungan senyawa kimia alkaloid, fenolik, dan triterpenoid. Semua jenis senyawa tersebut diketahui memiliki aktivitas antioksidan. ${ }^{1}$

Senyawa flavonoid, fenolik dan tanin merupakan senyawa yang bertanggung jawab terhadap aktivitas antioksidan. ${ }^{23,24}$ Kemampuan senyawa flavonoid dan fenolik sebagai antioksidan pada tanaman herbal seperti daun surian (Toona sureni) ${ }^{23}$, buah jamblang (Syzygium cumini) ${ }^{23}$, umbi bawang dayak (Eleutherine palmifolia) ${ }^{1}$, daun bawang mekah (Eleutherine americana) ${ }^{23}$, dan beberapa genus bawang (Allium $s p)^{5}$ telah dibuktikan oleh banyak peneliti di seluruh dunia. ${ }^{1,5,23}$

Aktivitas antioksidan pada senyawa flavonoid, fenolik dan tanin dikarenakan ketiga senyawa tersebut adalah senyawa-senyawa fenol, yaitu senyawa dengan gugus $-\mathrm{OH}$ yang terikat pada karbon cincin aromatik. Senyawa fenol ini mempunyai kemampuan untuk menyumbangkan atom hidrogen sehingga radikal DPPH dapat tereduksi menjadi bentuk yang lebih stabil. Aktivitas peredaman radikal bebas senyawa fenol dipengaruhi oleh jumlah dan posisi hidrogen fenolik dalam molekulnya. Semakin banyak jumlah gugus hidroksil yang dimiliki oleh senyawa fenol maka semakin besar aktivitas antioksidan yang dihasilkan. ${ }^{23,24}$

Selanjutnya pada penelitian ini didapatkan bahwa ketiga varietas bawang putih memiliki nilai aktivitas antioksidan $\left(\mathrm{IC}_{50}\right)$ pada rentang $10,61 \mathrm{mg} / \mathrm{ml}$ sampai dengan $13,61 \mathrm{mg} / \mathrm{ml}$ berarti bahwa berdasarkan klasifikasi nilai aktivitas antioksidan $\left(\mathrm{IC}_{50}\right)$ yaitu $10 \mathrm{mg} / \mathrm{ml}<\mathrm{IC} 50<30$ $\mathrm{mg} / \mathrm{ml}$ termasuk kedalam mempunyai aktivitas antioksidan yang sedang. ${ }^{25}$ Bawang putih lokal siung tunggal memiliki daya antioksidan yang lebih baik dibandingkan dengan varietas bawang putih lainnya walaupun memiliki kandungan senyawa yang sama. Oleh karena itu perlu dilakukan penelitian selanjutnya mengenai uji kandungan total fenolik dan uji kandungan total flavonoid pada ketiga varietas bawang putih untuk mengetahui kandungan total senyawa fenolik dan flavonoid pada masing-masing varietas tersebut.

Penelitian lain didapatkan bahwa aktivitas antioksidan secara in vitro pada bawang putih dilakukan secara ekstrak menggunakan pelarut hidroethanol $15 \%$ yang direndam selama lebih dari 20 bulan atau biasa desebut dengan istilah Age Garlic Extract (AGE) memiliki aktivitas antioksidan yang terbaik dibandingkan dilakukan cara ekstraksi dengan dipotong langsung atau biasa dikenal dengan Raw Garlic Extract (RGE) dan yang dipanaskan Heated Garlic Extract (HGE) menggunakan pelarut selain hidroetanol $15 \% .{ }^{26}$ Kandungan organosulfur dan polifenol merupakan faktor yang penting dan bertanggungjawab terhadap daya aktivitas antioksidan pada bawang putih (Allium sativum) tersebut. ${ }^{26}$

Penelitian yang dilakukan oleh para peneliti sebelumnya menyatakan bahwa hasil analisis 
aktivitas antioksidan bawang putih dengan uji antioksidan metode Total Phenolic Content (TPC) sebesar 61,44 $\pm 1,12 \mathrm{mg}$ $\mathrm{GAE} / \mathrm{g}$, nilai tersebut masuk dalam klasifikasi nilai aktivitas yang sedang. ${ }^{25}$ Klasifikasi nilai aktivitas antioksidan kandungan total fenolik (TPC) yaitu tinggi jika > $70 \mathrm{mg} \mathrm{GAE} / \mathrm{g}$, sedang jika nilainya 10-70 $\mathrm{mg}$ GAE/g dan rendah jika mempunyai nilai $<10 \mathrm{mg}$ GAE $/ \mathrm{g} .{ }^{25}$ Nilai aktivitas antioksidan metode Total Phenolic Content (TPC) tidaklah berbeda dengan apa yang telah dilakukan oleh peneliti dengan uji aktivitas antioksidan menggunakan metode DPPH (1,1-difenil-2-pikrilhidrazil) bawang putih.

Berdasarkan hasil penelitian diketahui bahwa bawang putih (Allium sativum) memiliki daya aktivitas antioksidan. Seluruh varietas bawang putih yang dijadikan sampel pada penelitian ini memiliki daya aktivitas antioksidan yang termasuk klasifikasi aktivitas antioksidan yang sedang dan varietas bawang putih lokal siung tunggal memiliki daya aktivitas antioksidan yang lebih baik dibandingkan varietas yang lainnya.

\section{KESIMPULAN}

1. Ketiga jenis varietas ekstrak bawang putih (Allium sativum) memiliki kandungan yang bermanfaat sebagai antioksidan.

2. Terdapat perbedaan nilai aktivitas antioksidan varietas bawang putih yang memiliki daya antioksidan pada ketiga jenis varietas bawang putih (Allium sativum) dan yang paling baik yaitu bawang putih lokal siung tunggal.

\section{DAFTAR PUSTAKA}

1. Andi E.F dkk. Kapasitas antioksidan dan inhibitor alfa glukosidase ekstrak umbi Bawang Dayak. J Teknol. Dan Industri Pangan Vol. 24(2): 161-167.
2013.

2. Adi A.S dkk. Penentuan kandungan fenolik total dan aktivitas antioksidan dari rambut jagung (Zea mays L) yang tumbuh di daerah Gorontalo. Jurnal Sainstek. Vol. 7(3). 2013.

3. Ghazala H.R \& Huma S. Genus Allium: The potential nutritive and therapeutic source. Journal of Pharmacy and Nutrition Sciences 1: 158-165. 2011.

4. Harini K, Babu S, Ajila V \& Hegde S. Garlic: It's a role in oral and systemic Health. NUJHS 3(4): 17-22. 2013

5. Gawad M.A, Aziz M.A., Sayed M.E., Wakil E.E. \& Lateef E.A. In vitro antioxidant, total phenolic and flavonoid contents of six allium species growing in Egypt. Journal of Microbiology, Biotechnology and Food Sciences 3(4): 343-346. 2014.

6. Anna Capasso. Antioxidant action and therapeutic efficacy of Allium sativum L. Molecules 18: 690-700. 2013

7. P.Bhuvaneswari. Antioxidant in Oral Healthcare. J Pharm Sci \& Res Vol.6 (4): 206-209. 2014.

8. Arvind Shetti, Vaishali Keluskar \& Ashish Aggarwal. Antioxidants: Enhancing oral and general health. JIAOMR 21(1): 1-6. 2009.

9. Nimmi Singh et all. Antioxidants in oral health and disease: future prospects. IOSR-JDMS Vol.10(3): 36-40. 2013.

10. Ahmadi Motamayel,F. Oxidative stress and antioxidant. DJH Vol. 3 (1): 1-11. 2011.

11. Durairaj S, Srinivasan S, Lhaksamanaperumalsamy P. In vitro antibacterial activity and stability of garlic extract at different $\mathrm{pH}$ and temperature. Electronic Journal of Biology 5(1): 5-10. 2009.

12. Kakhia T.I. A round in alcohols world between production, properties, uses, applications, fuel, \& compounds. http://tarek.kakhia.org/books eng/ Alcohol.Tarek_Kakhia.pdf. [Diunduh tanggal 05 November 2017].

13. Sukhdev $\mathrm{SH}$ et al. Extraction technologies for medicinal technologies and aromatic plants. United Nations Industrial Development Organization and the International Centre for Science and High Technology: 1-266. 2008.

14. Saeed A.S \& Ahmed B. Qualitative analysis of various component of Allium sativum (fresh garlic bulb), extracted in different organik solvents using GC-high resolution mass spectrophotometer (JMS700). International Journal of Current Research in Chemistry and Pharmaceutical Sciences 1(8): 122126. 2014.

15. Umesh K, Chavan S \& Tumpidi P. Effect of bitter gourd against $S$. mutans and L.acidophilus an in vitro study. International Ayurvedic Medical Journal. MayJune 2(3): 374-379. 2014.

16. Heryuliani Purwanti. Perbedaan efek penghambatan karies gigi antara ekstrak etanol bawang putih (Allium sativum) dan natrium fluorida secara in vitro. Tesis FKG Unpad. 2014.

17. Jebakumar A.Z, Hassan S.N, Siju K.G, Manoj G. Natural anti-oxidants and in-vitro method for anti- 
oxidant activity. IJBR 2(1): 46-55. 2012

18. Philip Molyneux. The use of the stable free radical diphenylpicryl-hydrazil (DPPH) for estimating antioxidant activity. Songklanakarin J Sci Technol 26(2): 211-219. 2004

19. Irda Fidrianny et al. Antioxidant activities of various fruit extract from three Solanum sp using DPPH and ABTS method and correlation with phenolic, flavonoid and carotenoid content. J Chem pharm.Res 7(5): 666-672. 2015.

20. Deepshikha G. Method for determination of antioxidant capacity : a review. IJPSR Vol.6(2): 546566. 2015.

21. Hyung Chun. Characterization of antioxidant activities of soybeans and assessment of their bioaccessibility after in vitro digestion. Blacksburg,Virginia : 1-136. 2009.

22. Suwannaporn B. et al. The antioxidant and anticadmium toxicity properties of garlic extracts. Food Science \& Nutrition 2(6): 792-801. 2014.
23. Dina P. dkk. The test of antioxidant activity from bawang mekah leaves (Eleutherine American MERR.) using DPPH (2,2-Diphenyl-1-Picrylhydrazyl) method. Trad Med Journal Vol. 18(1): 9-16. 2013.

24. Chao Z.L. et al. Structure-activity relationships of antioxidant activity in vitro about flavonoids isolated from pyrethrum tatsienense. JICEP 3(3): 123 - 127. 2014.

25. Safaa Y.Q., Ahmed N.A. \& Mona A.L. Screening of antioxidant activity and phenolic content of selected food items cited in the holly quran. EJBS 2(1): 40-51. 2010.

26. Anna Capasso. Antioxidant action and therapeutic efficacy of Allium sativum L. Molecules 18: 690-700. 2013. 